Article

\title{
The Tenure Guidelines in Policy and Practice: Democratizing Land Control in Guatemala
}

\section{Salena Fay Tramel}

Political Ecology research group, International Institute of Social Studies, The Hague 2518 AX, The Netherlands; tramel@iss.nl

Received: 23 September 2019; Accepted: 16 October 2019; Published: 6 November 2019

Abstract: This paper explores the challenges for democratizing land and natural resource control in Guatemala through use of the Voluntary Guidelines on the Responsible Governance of Tenure of Land, Fisheries, and Forests (Tenure Guidelines). This international human rights instrument comes at a critical moment, in which the current global land rush has shaped contemporary agrarian transformation with serious implications for the right to food and control of natural resources. The Tenure Guidelines provide us with a unique opportunity to put land and natural resource tenure squarely under the prescriptions of international human rights law, rather than allowing tenure to be subsumed by a narrow understanding of property rights based on civil and merchant law. In Guatemala, we are witnessing a political opening, where the government has incorporated the language of the Tenure Guidelines into its regulatory framework unlike any other country in Latin America. At the same time, the world watches on while a slow-motion coup engulfs the Central American country, reflecting a global trend of gutting democracies and coopting the language and legislation meant to protect them. Thus, the implementation of the Tenure Guidelines is strongly contested by state and corporate actors seeking to use the instrument in order to gain political legitimacy for the expansion of agribusiness like oil palm and sugarcane, and other forms of extractive industry. This paper's findings indicate that when applied together with a rights-based approach, the Tenure Guidelines are a powerful social and political tool. Such is especially true of the most marginalized populations who require protection and respect for their existing tenure rights, promotion of reforms for better access to and control over land and resources, and restoration of tenure rights resulting from displacement or dispossession.

Keywords: Tenure Guidelines; agrarian transformation; environmental justice; conflict resolution; land policy; Guatemala

\section{Introduction}

Stark contradictions mark land and natural resource politics in Guatemala. Deep in the country's northern lowlands, a labyrinthine grid of oil palm plantations nearly encloses the Mayan Q'eqchi' village of Sachaj. A lone road connects the hamlet to the world beyond the thick trees, and along that route, one can catch a glimpse of the few remaining household farms that compete with the large corporations for water. But it is not just Sachaj that is being squeezed under the weight of agribusiness. Working people—especially those who are Indigenous and rural—confront various interlinked land accumulation processes as industries such as oil palm expand in Guatemalan and global marketplaces. This is happening with the blessing of the state, and is sold with promises of food security and job creation that are impossible to fulfill. At the local level in Sachaj and in other affected communities, who gets what in this latest phase of an agricultural economy that has routinely marginalized peasants? How much do they get, why, and for what purpose [1]? These questions offer a framework that fuses democratic land control with human rights. At its core, democratic land control is political 
economy terminology for the 'human right to land' [2], an emerging concept in which food sovereignty, environmental justice, and territory are inseparable. A right to land would both protect land users' rights and oblige states to roll out land reform strategies in cases where strengthening access to natural resources is necessary, to fully realize the right to food [3].

Realities on the ground point to alarming extractive practices that contribute to rural hunger and malnutrition, environmental degradation and climate change, and operate outside of the rule of law-and they converge pointedly on the land angle. Paradoxically, while growing the majority of the world's food, approximately 700 million of the global small-scale food producers and agricultural workers are going hungry [3]. In Guatemala, more than 70 percent of the Indigenous and rural population depends on agriculture, often in the form of small-scale peasant production, primarily growing maize on their own or rented land. Up to fifty percent of Guatemalan children suffer from chronic malnutrition - amounting to the highest rate in Latin America, and among the highest in the world-and the overwhelming majority of them are Indigenous [4]. Effective access to land and water resources can therefore be a literal matter of life and death. In these cases, waiting for the state to fulfill its duties to all of its citizens is simply not a viable option.

International human rights legislation and normative frameworks can help fill the gaps between policy, practice, and ultimately empowerment-when correctly interpreted with the pro-poor bias with which they were written. The UN World Committee on Food Security and Nutrition (CFS) Voluntary Guidelines on the Responsible Governance of Tenure of Land, Fisheries, and Forests in the Context of National Food Security (hereafter Tenure Guidelines [5]), delivered in 2012, has set a new global standard for land tenure from a human rights perspective (see [6,7] for further discussion on the Tenure Guidelines generally, [8,9] for regional insights from Africa and Latin America, respectively, and [10,11] for Colombia and Myanmar, respectively). It is currently the only international instrument dedicated to land, fisheries, and forests and it contains a set of minimum standards that states can put into effect to democratize access to and control over land, water, and connected natural resources for their 'most vulnerable and marginalized' citizens (Tenure Guidelines 1.1).

Guatemala is particularly relevant in that not only has it endorsed the Tenure Guidelines, but it has also reportedly modeled its 2014 Agrarian Policy after language contained in the guidelines [12]. Today, with resource grabbing on the rise and the rule of law further unraveling in the Central American country, it is safe to assume that these guidelines were not used in the way in which they were intended. Rather than righting historical wrongs and preventing future harm to the most vulnerable populations-especially women, peasants, and/or Indigenous peoples—the guidelines have been largely coopted in Guatemala as an instrument to legitimize agribusiness and other megaprojects. What does this indicate for Guatemala's agrarian and environmental trajectories? Is there any hope to glean strategic political insight from the Tenure Guidelines now that they have moved further out of the limelight? And, what does the future look like when signatory states are coopting and watering down such tools?

These are just some of the questions that led a team of researchers to Guatemala and Colombia in 2015 to assess the Tenure Guidelines in a collaborative project between the UN Food and Agricultural Organization (FAO) and the International Institute of Social Studies (ISS) in The Hague. That process brought us face to face with a host of governmental officials, NGOs, academics, peasant and Indigenous organizations, and social movements, among others. Given the high levels of agrarian and environmental conflict in Guatemala, we chose to zoom in on a particular community, Sachaj, a village nestled deep in the Raxruhá municipality of the Alta Verapaz district. We did so at the invitation of local activists and researchers. Once we anchored ourselves in a localized setting that was indicative of similar accumulation projects throughout the country, we zoomed back out to the national and global scales, through our analysis of Agrarian Policy and the Tenure Guidelines, respectively. This project inspired a variety of political and academic outputs, and this paper comes from that lineage; some of the findings of a much earlier version were published and presented as part of Initiatives in Critical Agrarian Studies [13]. 
This paper is guided by a right to land framework that is encapsulated in the Tenure Guidelines and serves as a launching platform for related human rights. This framework is built on the needs of rural workers, including the most exposed subsets within that population, such as women and Indigenous people. Land control is problematized here as an issue of access, necessitating 'the ability to derive benefits from things' rather than only 'the right to benefit from things' [14]. From here, two types of land tenure policies emerge to help secure rural working peoples' access to and control over land, fisheries and forests. Simultaneously, policy should respect and protect democratic land access where it already exists, and promote and restore democratic land control where it is absent [2] (see illustration in Figure 1, below). These key concepts form the theoretical spine of this paper.

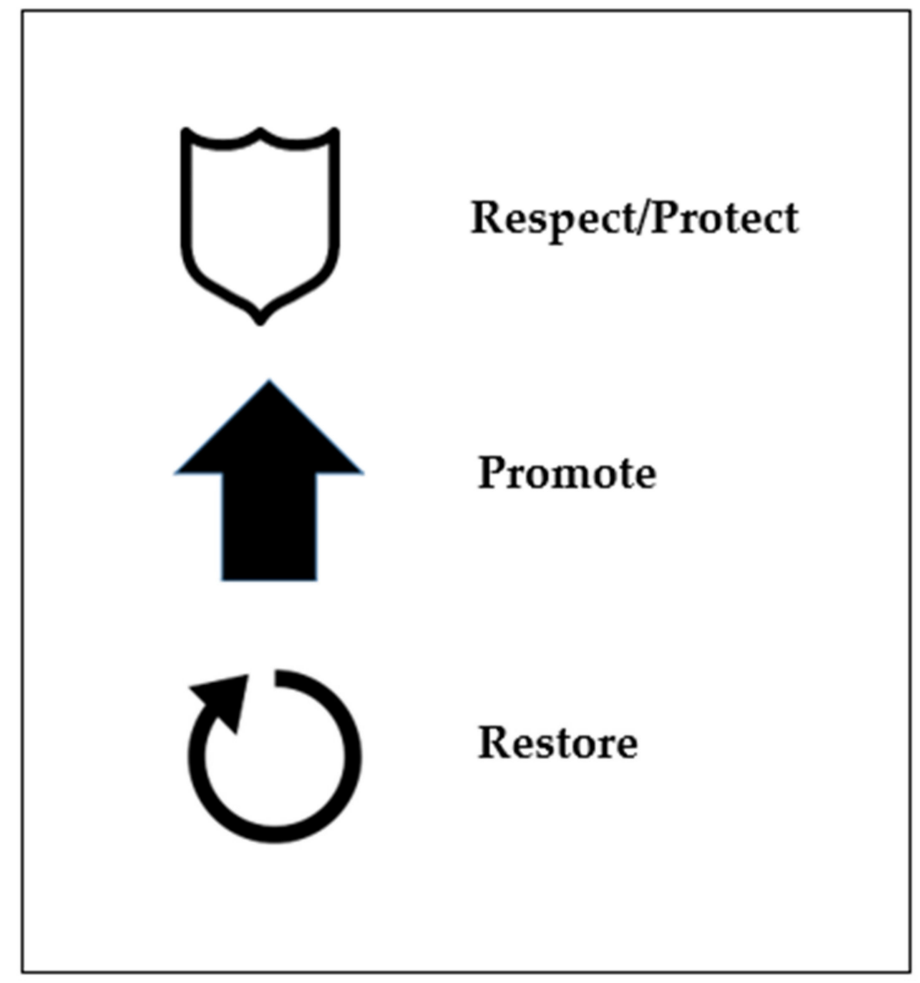

Figure 1. Democratic land control.

First, in settings where rural working people have existing access to land, water, forest, and other natural resources, but contemporary political economic processes threaten it, there is a need to respect and protect that access. Second, in settings where rural working people have no existing access to land, water, forest, and other natural resources, but not as a result of violent expulsion from, or fraudulent or distressed loss of their previous homeland or communities, there is a need to promulgate and promote (re)distributive reforms. Finally, in settings where rural working people have no existing access to land, water, forest, and other natural resources, and this is the result of past violent expulsion from, or fraudulent or distressed loss of, their previous homeland or communities, there is a need to restore their access via land restitution and other vehicles [2]. This paper applies this framework—'respect/protect, promote, restore' — to Guatemala's Agrarian Policy using the Tenure Guidelines in a way that is telling of power relations and that may resonate elsewhere.

This paper positions Guatemala's agrarian trajectory within the minimum standards set by the Tenure Guidelines. Such is done in an attempt to assess not only national policies and institutions, but also their potentials in relation to marginalized, vulnerable, and frontline populations throughout the Guatemalan rural landscape. In some cases, regulatory frameworks exist, but only in a partial, dormant, or contradictory way; in other cases, regulatory frameworks are absent. The paper explores four axes of Guatemala's Agrarian Policy: 1) land access, 2) resolution of agrarian conflicts, 3) legal guarantees and security, and, 4) access to other productive assets (see elaboration in Figure 2, below). It also targets 
other regulatory instruments at different geographical scales, for instance, the Constitution, the Peace Accords, and municipal legislation. An examination of the state and corporate actors indicated in these regulatory frameworks cuts across all points of this discussion, at the same time intersecting with related recommendations written into the Tenure Guidelines. It is important to note here that while Guatemala's historical and institutional factors are explained in brief where possible, a thorough study of these particularities is beyond the scope of this paper.

\section{Land access}

Ensuring that communities or landless organized family groups living in poverty have access to land. Prioritizing women as a fundamental element for achieving food and nutrition security in the context of integrated rural development.

\section{Resolution of agrarian conflicts}

More focus on and resolution of agrarian conflicts using alternative measures and through appropriate legal avenues, with gender equality and respect for multiculturalism.

\section{Legal guarantees and security}

Ensuring certainty and legal guarantees of ownership, possession and tenure of land, based on appropriate legislations and institutions.

\section{Other productive assets}

Facilitating access to other productive assets to boost the peasant economy, principally family agriculture, to ensure food security and promote sustainable and competitive activities, enabling a link to the national and international market.

Figure 2. Axes of Guatemala's agrarian policy.

The discussion probes the overlaps and gaps between the Tenure Guidelines and regulatory frameworks across Guatemala in the three broad contexts of the 'respect/protect, promote, restore' framework. First, it examines safeguards, and public land, fisheries, and forests-where rural poor people's access to land and natural resources is threatened. This includes those who have access without land tenure, and others who have land tenure rights but no (real) access. Second, it highlights redistributive reforms, and informal tenure as methods to achieve a comprehensive agrarian reform 
for the (near) landless. Finally, it explores restitution to restore land and resources to populations that were violently displaced, or evicted or uprooted by fraudulent means.

The provisions in the Tenure Guidelines mentioned above are integrated with additional measures therein that coincide with priority areas pointed out in Guatemala's Agrarian Policy, namely, Indigenous peoples and other communities with customary tenure systems, markets, and investments. Each of these recommendations should be considered in the context of the guiding principles of responsible tenure governance that are outlined in the opening section of the Tenure Guidelines. This set of priorities is further complemented by-and is thus intended to work with-other human rights-based global governance tools, especially Free Prior and Informed Consent (FPIC), the Rights of Indigenous Peoples, the Rights of Peasants and Other People Working in Rural Areas, the Right to Food, and Convention 169 of the International Labor Organization.

The Tenure Guidelines apply to a variety of settings, which are analyzed in this paper. In settings where policies to protect, promote, or restore land tenure are absent, as in the case of promoting comprehensive agrarian reform, the Tenure Guidelines can act as a guide to develop regulatory frameworks to grant rights to vulnerable groups like landless workers. Across settings where land access is recognized but contradictory, the Tenure Guidelines provide indications for regulatory frameworks to correct such contradiction(s) - a decisive example being women's land rights, in which context the legislation being used to promote those rights can actually thwart them. This is often the case in Guatemala. In settings where restorative and other land and resource policies exist but in a way that is insufficient in partial laws, the Tenure Guidelines can suggest how to fill the gap. This is best exemplified in Guatemala where restitution is part of the policy, but not one that recognizes its most marginalized victims of violent crisis and expulsion-especially refugees of the Civil War and its notorious scorched earth campaigns (let alone those who lost their land access due to fraud or distressed sales). Finally, in settings where adequate policies exist, but are dormant, the Tenure Guidelines serve to facilitate their implementation — grassroots efforts to boost peasant economies with strong state support are key examples of this. These political settings are regional and global in their insights and implications.

Above all, the Tenure Guidelines can serve as a set of minimum standards, based on human rights, which can be used to reflect on and measure the relevance and effectiveness of what is in place on the ground, and what is lacking. This applies especially to the regulatory capacities of different state actors-from executive to judiciary to legislative-in the quest to democratize land, fisheries, and forest tenure.

The Tenure Guidelines come at a time in which human rights instruments are profoundly relevant and politically urgent at scale. In Sachaj, the David vs. Goliath face-off continues between the oil palm industry and rural Indigenous people who are landless or threatened with landlessness by the shrinking enclosure. This community battle is indicative of similar struggles throughout Guatemala, and telling of an agrarian trajectory with regional and international consequences. When used in collaboration with participatory signatory states to inform national legislation, the Tenure Guidelines can help in identifying gaps, absences, and contradictions in current regulatory frameworks around the needs to protect and respect, promote, and restitute the tenure rights of the most vulnerable and marginalized. The Tenure Guidelines are also highly prone to cooption, as has been proven in Guatemala. Such necessitates space for more vigilant application of rights that apply to the participatory governance of land and territory.

The remainder of this paper is organized as follows. First, it provides some broad brushstrokes of key social and institutional actors related to land in Guatemala. Following this are three sections based on the respect/protect, promote, restore framework; in each of these, Guatemala's Agrarian Policy is assessed against the Tenure Guidelines. The paper then concludes with recommendations that are part of a wider synthesis. 


\section{Trajectories and Actors of Land Politics in Guatemala}

Guatemala has some of the most unequal land distribution in the world. The Gini Coefficient with respect to the concentration of tenure and land ownership rose from 0.82 in 1979 to 0.84 in 2003, the year the most recent agrarian census was conducted in Guatemala [15]. This number reflects the fact that after the turn of the millennium, 78 percent of arable land was already concentrated in the hands of 8 percent of landholders-both setting the backdrop for this latest investment boom on the heels of the 2007-2008 food crisis and violating the human rights of many Guatemalans working in the countryside, in particular, their right to food.

Access to and control over land is a fundamental starting point for natural resource governance and fulfilling the right to food and nutrition. Across all of its functions, land holds or surrounds other resources-forests, water, and minerals-making it the point of departure for agrarian-environmental transformation processes. In some circumstances, including for sugarcane and oil palm agribusiness, land is key to securing cheap labor such as contract farming. For many groups of people, land is territory-signifying that it is much more than just an economic production factor, but laden with socio-cultural reproduction factors along with ancestral, and spiritual significance (see [16-19] among others). Because of this, reducing land to just one of these factors-as states often do when dealing with records rather than people-amounts to a dangerous form of oversimplification and alteration of territory-based social and ecological interactions.

The current global land rush exploded in 2007-2008 as the food, energy, financial, and climate crises converged while the BRICS (Brazil, Russia, India, China, and South Africa) and even some prominent MICs (Middle Income Countries) created new hubs of capital accumulation [20]. One of the most telling trends of this current phase in land acquisition is the mushrooming demand for 'flex' crops, crops that have multiple uses as food, animal feed, and fuel, among others (see [21] for general implications of flex crops, and [22] on oil palm, [23] on sugarcane, and [24] on flex trees). Thus, according to the industries controlling them, these crops have the potential to solve multiple crises, and at the same time provide safe investment opportunities within the global food regime [25]. Flex crops are grown on what are assumed to be marginal lands, with the blessing of cash-strapped states that claim these lands are available. Two of the most prominent flex crops globally are oil palm and sugarcane, which have been scrutinized widely as instances of land grabbing.

At the height of the global crisis in 2008, Guatemala declared over a million hectares of land-amounting to 37 percent of its total farmland-to be available for oil palm and sugarcane cultivation [26]. At the same time, the World Bank called agriculture good business, with the potential for poverty alleviation [27] —noting that in urbanized countries agriculture acts in a similar way to other exchangeable economic sectors that are up for trade. This underpinning notion of agriculture as an export commodity is echoed throughout Guatemala's regulatory instruments. The oil palm industry has become integral to securing Guatemala's spot in the world food regime, and the role of the state in these greater dynamics should not be underestimated [28]. In the Raxruhá municipality of the Alta Verapaz district, agriculture is big business indeed, as seen through reduced family farming in villages like Sachaj due to oil palm expansion and ensuing grievances and conflict (see [29,30]). The Sachaj community offered a collection of their observed complaints in the following communication.

Oil palm plantations in our town are causing serious harm, which includes: nonpayment of property tax, damage to road infrastructure, land grabbing, labor exploitation, pollution of potable water sources, pressure from businesses on community leaders and families to sell their land, violation of right of way between neighboring communities, use of coercive force, violence against peasant families, destruction of forests and jungles, altering the way of life of the communities... acts of pressure, coercion, threats and intimidation by oil palm companies, intermediaries (coyotes) or by government officials in the sale of plots, to leaders, authorities, organizations or people who protest freely to be able to express our opinions, and defend our rights, to define different strategies in order for the companies to improve the living conditions of the people of Raxruhá (community press release, dated 14 June 2013). 
Agrarian and environmental justice movements made up of peasants and Indigenous peoples throughout Guatemala insist that their land struggles are linked to a 'defense of territory' masterframe. Defense of territory brings out indivisible interconnections-between land, nature, body, and other elements. In this context, land politics issues have everything to do with culture and identity, as well as with politics and economics. And because of its broad scope, defense of territory further serves as a platform for convergence-of issues, of movements, and of campaigns. Even if a thorough mapping of social justice movements is beyond the reach of this paper (see [31] for a detailed analysis of rural Guatemalan movements), it is relevant to mention a few key actors-especially as changes at the highest political levels are often the direct result of political actions from below. For the purposes of this discussion, examples of movements engaging with 'defense of territory', and that are using or have the political will or potential to use the Tenure Guidelines, are highlighted here at scale. In addition, the social movement actors that follow were consulted with to varying degrees over the course of the two visits to Guatemala that were conducted for this study.

At the most local level in the Raxuhá and neighboring Chisec municipalities, Sa Qa Chol Nimla K'aleb'aal (SANK) is a grassroots Mayan Q'eqchi' movement that started out as a youth organization and grew to focus more broadly on agrarian justice-using agroecology as an engine for food sovereignty. Today they maintain a network of producers and markets. On the legal side, SANK has invested its efforts in winning communal land titles and communal management of protected areas. It has seen varied degrees of success in these areas, while also keeping constant watch over the oil palm corporations.

The most important national organization in Guatemala is arguably the Peasant's Unity Committee (CUC). It was founded in 1978 as the first national movement of peasants and Indigenous peoples. Over its four decades of experience, CUC has fine-tuned its working areas into a carefully constructed tripod for social change: access to land, defense of territory, and building a peasant and Indigenous economy. The movement has further focused its work in communities facing displacement or environmental damage by mining, dams, and industrial agriculture. What was lacking in the broader movement was a political connection to the parts of Alta Verapaz where SANK was a well-known force. Although these two organizations do not have an official affiliation with one another, they have built a mutually reinforcing working relationship in order to reach power at scales they would not be able to access on their own.

Guatemalan social movements take their agrarian struggles beyond state borders through affiliation with regional and global movements. CUC is linked with the Latin American Coordination of Rural Organizations (CLOC) and is also one of two Guatemalan members of the transnational agrarian movement La Vía Campesina. There are similar conduits for allied environmental justice movements, most notably through affiliation with Friends of the Earth International. The Association for the Promotion and Development of the Community (CEIBA) is the Guatemalan branch of that global environmental network. These organizations are significant in that they are articulating a vision of system change where agroecology acts as the intersection and path to food sovereignty and environmental/climate justice [32-34]. A way of achieving these kinds of changes is targeted work with key global governance instruments - and the Tenure Guidelines are among the most relevant.

Meanwhile, existing Guatemalan land tenure policies, particularly those written into the Agrarian Policy, are rooted in two relatively recent keystone documents: the 1985 constitution and the 1996 Peace Accords. Both were written at a time when neoliberal globalization was morphing into the dominant economic order. Article 39 of the 1985 Guatemalan constitution (reformed in November 1993) presented private property as an inherent 'citizen right', elaborating that it is the state's responsibility to carry out access with the assumed dual benefit of individual progress and national development (Government of Guatemala 1993: 9 [35]. Paralleling the private property tenure mechanism, the constitution also outlined communal and collective tenure in article 67 where it referenced protection of Indigenous land and agricultural cooperatives. The article further stipulates that lands in the hands of Indigenous communities or cooperatives that desire other forms of communal or collective agrarian land tenure 
(also including housing and family property) are to benefit from special protection by the state, preferred credit, and technical assistance to improve quality of life for all inhabitants. Of further relevance to Guatemala's rural majority, the article stipulates that lands which have historically belonged to Indigenous communities and have traditionally been administered by them in a special manner will maintain those systems of governance (Government of Guatemala 1993: 13 [35]).

Collectivity and tenure have been further addressed in Order 41-2005 of the Law of the Registry of Cadastral Information. This particular order defines collective, or communal, tenure as it applies to lands in ownership, possession, or tenure of Indigenous or peasant communities as collective entities, with or without personal jurisdiction. The Registry of Cadastral Information was directly linked to the 1996 Peace Accords that was said to prioritize land access for the rural poor. Yet, the entire process and its outcomes were dominated by a powerful Guatemalan elite and the World Bank and International Monetary Fund, among other international financial institutions [36,37], leaving out real structural reforms to address the root cause of poverty in the rural agricultural sector [38]. Additionally, communal land tenure is often an example of 'partially' available land. For instance, communal tenure is not recognized in protected areas-even in cases where people have been dwelling in forests and dependent on those forest resources, since before they were officially declared 'protected areas'. Put simply, land and resource access have often been supported in principle on paper, but not honored in practice on the ground.

After the Peace Accords were officially signed, with prioritized commitments addressing 'Socioeconomic Aspects and the Agrarian Situation', the National Land Fund (hereafter FONTIERRAS) was created. This autonomous entity has stated an overarching objective to facilitate the transfer of lands to landless peasants. More specifically, the institution intended to 'drive the land market' via two parallel policy platforms-'regularization' and 'access'. FONTIERRAS operates with World Bank and Guatemalan government funds, and has been a key driver of market-led agrarian reform under a neoliberal development agenda [38]. According to Article 46 of the FONTIERRAS code of conduct, regularization refers to the process of analysis, revision and update of records documenting land sale and tenure, submitted or in process of submission, on behalf of the State. Access, as defined in Article 25 of the FONTIERRAS code of conduct, is achieved across three schemes: adjudication, grants of credits for land purchase, and grants of credits for land rental with or without the option to buy.

It is within these contours that Guatemala's Agrarian Policy was conceived, conceptualized as an indispensable component of the National Policy for Integral Rural Development spanning multiple sectors of society. It is important to note that FONTIERRAS and the Registry of Cadastral Information are two of the state institutions most responsible for implementing the Agrarian Policy at the local and national levels. Agrarian Policy threads together objectives, strategies, and instruments that its proponents say aspire to facilitate and increase land access, open a path to conflict resolution, roll out legal guarantees and security, and provide access to other productive assets [12]. These threads tie back to the Guatemalan government's conceptualization of land as an economic factor. More often than not, this has involved disregarding its political, social, and cultural aspects. Indeed, land titling and other related processes have often undermined access to and control over land and other natural resources for the most marginalized rural working people in the country (see [39-41] for further discussion).

The Tenure Guidelines provide a key departure point in addressing issues of power and political change in land policymaking that are key to state-society relations and achieving the kinds of changes movements seek at the political level. The following section offers a discussion that pits each axis of Guatemala's Agrarian Policy against the relevant recommendations agreed upon in the Tenure Guidelines by the states that ratified the mechanism. Since Guatemala is not only a signatory to these guidelines, but is advertising its new land policy as having been modeled by them, the country is positioned to set a regional example by adopting and implementing a democratic land policy that protects, promotes, and restores a human rights-centered approach to land and territory for all its citizens. Guatemalan policymakers have additionally cited other human rights treaties, particularly the Rights of Indigenous Peoples in their own legal safeguards. But at the core, there is a vast difference 
between rights making and making rights real [42], and yet another gap between implementation and empowerment [43].

\section{Respect and Protect-Land Access}

Guatemalan policies and institutions have repeatedly presented land access as a pressing issue. The first axis of the 2014 Agrarian Policy echoes the founding law of FONTIERRAS (no. 24-99), where land access is a prioritized vision that should be guaranteed by the state. When triangulating land access within Guatemala's political structure and institutions and the Tenure Guidelines, it is important to return to the definition of access referenced earlier, namely that access is the ability to derive benefits from things' rather than simply 'the right to benefit from things' [14]. This understanding of access calls for the resettling of control over natural resources in the hands of previously marginalized communities, thus building their political power.

Agrarian Policy in general, and its Land Access priority in particular, often recycles failed policies, tasking government institutions that have proven to be inapt with (re)implementing those policies throughout the countryside to solve the current impasse-repeating or risking repetition of cycles of rural poverty and dependency. Sale and leasing of land with or without the option to buy (Agrarian Policy 1.1) put FONTIERRAS at the helm of credit schemes and guarantee funds for the purchase and leasing of land, an arrangement that has repeatedly reaped disastrous outcomes. After the signing of the Peace Accords, Guatemala took on a Market Led Agrarian Reform (MLAR) program-thanks to political prodding and ample funding from the World Bank - to 'advocate for voluntary transactions between 'willing sellers' and 'willing buyers' and the removal of various 'distortions' from land and agricultural markets' [44].

FONTIERRAS was conceived as a state institution in this very manner and at that historical moment- to fund landless families through credit and subsidies and manage the national titling system (a responsibility that would be shared with the National Cadastral Registry from 2005 on). Throughout this process, FONTIERRAS failed miserably, managing to redistribute land to less than 5 percent of landless or near landless families in a national initiative that reached only 4 percent of Guatemala's arable land from 1997-2008. After 2009, FONTIERRAS only offered the option to lease land yearly, rather than buy it outright. Today, many spiral deeper into debt as they are not able to pay off the rising interest in addition to the principal of the original loans [45]. As of 2007, just as the global crises engulfed Guatemala, 80 percent of the beneficiaries of farm-land transfer under the MLAR program had fallen behind in their loan repayment and reported that it was impossible to ever pay such an amount in full [39].

These political procedures also coincided with a policy preference for individual land titling, starting from the time of the Peace Accords and continuing throughout the establishment of the Registry of Cadastral Information (RIC) and the Agrarian Policy discussed here. In a meeting with the community assembly, residents of Sachaj explained that they relied on an agrarian heritage that is highly communal in nature-since there was no individual title; no one person was able to sell their land entitlements in the absence of broad consent. The Peace Accords changed that with a new mandate on land administration authority, and with an emphasis on individual land titles (see [46] for more on land titles and the history of dispossession in Guatemala). On the one hand, this indeed upset communal land holdings. Yet on the other hand, many (Indigenous) peasants thought of individual land titling as the most powerful way to secure their tenure rights-imitating the way traditional large landowners made their claims to 'property rights' [45].

The Peace Accords and subsequently the Agrarian Policy included protections of marginalized groups, with an emphasis on women (see especially Agrarian Policy 1.3 on women's land access). However, the policy does so by highlighting subsidies and credits connected to individual titling, which may actually undermine women's land access. Decisions in rural communities are largely made by the male head-of-household, and with individual titling there is often little women can do to maintain plots for use by their own families and shield them for future generations. In one survey of 
land sales in the Northern Lowlands, half of men working in agribusiness plantations who headed households had sold their plots because they had become 'unproductive'. The other half said that they did so because they were 'highly indebted'. A reason stated by other men was that they had been 'forced' into a sale. Yet in the same survey, 86 percent of women heads of household blatantly opposed giving up their land at any cost [45]. Villagers in Sachaj saw FONTIERRAS coming in to issue land titles, and ever since then, they said, land sales are easily facilitated, and that the government had sold off its people's right to land. Those who remain on their plots reported pressure to sell, while those recently made landless explained that they had been threatened by various parties to make them vacate. Both scenarios have been deeply gendered, posing greater threats to women's rights (focus group with community in Sachaj, 1 April 2015).

Furthermore, having access to land and natural resources does not necessarily imply ownership. A first area of concern is land access under rental and usufruct agreements. Although much of the colonato and plantation economy is fading away, it remains an important factor in contemporary conflicts between landowners and workers. Under those systems, peasants survived at the intersection of tenancy and bonded labor arrangements with large landowners. Put simply, 'access to a plot of land for subsistence crop production (and housing), is conditional on performing labor-services on the landlord's estate' (Macours 2014: 8 [47]). What is left of that structure today leans more heavily on rental agreements and is rapidly commoditizing to give way to land leasing markets. Guatemalan regulatory framework addresses this within the Agrarian Policy where one of its stated goals is to transform Guatemala's colonato economy into a peasant economy (Agrarian Policy 1.4) through investment in productive infrastructure in addition to agreements between the state, employers ('patrones'), and settlers. 'Productive infrastructure' is extremely vague and open-ended language that can be used against the most vulnerable sectors of the population—especially when the deals often shift in reality toward the more powerful state and patrones.

The policy makes no mention of corporations such as the heavyweight oil palm or sugarcane industry (although they very well may be considered 'productive industry'), and they have the upper hand in relation to paralyzed local governments and traditional landlords, who have seen a decrease in income due to factors such as plummeting coffee or cattle prices. But it is sometimes these very actors - private sector agribusiness, the state, and traditional landed upper classes—that have a bottom line of profit in agricultural production, which may further marginalize the rural poor. Therefore, 'Productive infrastructure' can actually be used in a way that undermines the peasant economy, rather than encouraging it. Similarly, the Agrarian Policy contains language that endorses agreements between the state, employers, and settlers. This, combined with a renewed zest for land rentals from FONTIERRAS, raises the concern that preferred strategies to transform the agricultural sector will not benefit peasants and Indigenous people in the countryside.

A second area where people have access, but where that access is threatened, has to do with escalating environmental destruction and related health concerns as a consequence of oil palm expansion and other manifestations of agrarian extractivism, and the extractive industry as a whole. Clearly, land access is problematic in the face of growing farming, environmental, and health damage by third parties. When environmental grievances undermine the ecological terrain and people's health, the possession of individual or collective land titles becomes a secondary issue to survival. Deforestation, river diversions, and water scarcity and contamination are commonplace when space is made for water-intensive crops such as oil palm and sugarcane plantations throughout Guatemala (meeting with communities 22 April 2015).

In Sachaj, community members said that their maize cultivation was greatly diminished in the face of oil palm expansion. They explained with alarm that their environment has changed drastically due to toxic pesticides, and that local water sources have been poisoned in the process of oil palm expansion. Various community members pointed out yellowish green rivers that that had once been crystal blue, while data was being collected in the field for this study. (This issue was also highlighted the Mayor of Raxruhá in an interview on 1 April 2015 and in a gathering with communities affected by 
oil palm in Alta Verapaz on 22 April 2015).The issue of food security was of equal concern in Sachaj. Almost all of those who do own land there once cultivated basic crops for their own subsistence such as corn and beans, and today no longer have sufficient planting space-even with technical land access - and many of those people are now working as day laborers on the oil palm plantation. New illnesses are creeping up in Sachaj, such as stomach problems and a skin condition that affects children and is very difficult to treat. These farming, environmental, and health consequences of corporate oil palm cultivation also constrain working people's access to land, but such cases of 'indirect' constraint of access to land by third parties are not addressed in the current Agrarian Policy.

Although land access is a key priority in the Agrarian Policy and forms its first axis, the devil is in the detail. This is where the Tenure Guidelines can be used to hold authorities accountable for a land access foundation that works for the most marginalized. The first building block for protecting (threatened) access for rural frontline communities is a full understanding of the guiding principles of tenure governance that is mapped out in detail in section three of the Tenure Guidelines. It stipulates that states should 'recognize and respect all legitimate tenure right holders and their rights. They should take reasonable measures to identify, record and respect legitimate tenure right holders and their rights, whether formally recorded or not; to refrain from infringement of tenure rights of others; and to meet the duties associated with tenure rights' (Tenure Guidelines 3.1).

This is overlooked in the current policy wherein land access is dealt with through sale and leasing (Agrarian Policy 1.1.). It further identifies land as economic in function (Agrarian Policy 1.4) and prioritizes 'productive infrastructure' (Agrarian Policy 1.5). Although these and other policy points addressed in Axis I: Land Access of the Agrarian Policy are important marks of contention, especially regarding women's land access, a human rights approach to land tenure would be one that is rooted in the sort of rights-based language that we see throughout the Tenure Guidelines. These human rights aspects are clearly outlined in the sections of the Tenure Guidelines that speak to: human dignity (1.) with an emphasis on human rights, equality, and justice (2.) as it empowers highly marginalized populations; rule of law (7.) in relation to the past failure of institutions such as FONTIERRAS and RIC to follow through on promises to those who currently have access to land and resources; and finally, in that vein, accountability (8.) to hold all parties accountable to rule of law and other connected principles). In contrast, the language in the Agrarian Policy is not rights-based, but rather vision-based, perhaps in order to avoid infringement responsibility. It underscores economic potential (therefore, threatening the rights of those who may stand in the way), and moves away from a genuine discussion of 'legitimate holders of tenure rights' (that when identified, must be protected by all measures including international rights treaties to which the state is held accountable or bound).

Sections seven (Safeguards) and eight (Public land, forests, and fisheries) of the Tenure Guidelines provide additional guidance to ensure protection of land access. As previously discussed, many working people in the countryside enjoy access to land not as owners, but through different rental or usufruct agreements with wealthy landowners, mostly on large colonato landholdings. In the absence of proper safeguards, these groups of people are under serious threat of loss of access and livelihood. Within the legal recognition and allocation of tenure rights and duties, outlined in the safeguards of the Tenure Guidelines, what is said with respect to these rental agreements is as follows: 'when States recognize or allocate tenure rights to land, fisheries, and forests, they should establish, in accordance with national laws, safeguards to avoid infringing on or extinguishing tenure rights of others, including legitimate tenure rights that are not currently protected by law. In particular, safeguards should protect women and the vulnerable who hold subsidiary tenure rights, such as gathering rights' (Tenure Guidelines 7.1). These safeguards can also be used to improve usufruct land use strategy, specifically when the legal recognition of tenure rights is not possible. In this regard, the guidelines stipulate that: 'States should prevent forced evictions that are inconsistent with their existing obligations under national and international law [ ... ]' (Tenure Guidelines 7.6). By preventing forced evictions, states are both protecting rural land access for the marginalized and avoiding situations that require comprehensive agrarian reform and complicated restitution—both of 
which are discussed in this paper. The implementation of such safeguards could improve access by preventing procedural loopholes.

Section eight of the Tenure Guidelines can be invoked to protect and respect public land, forests, and fisheries in cases of compromised land access due to environmental and health issues as exacerbated by a third party. Thus, 'where States own or control land, fisheries, and forests, they should determine the use and control of these resources in light of broader social, economic, and environmental objectives. They should ensure that all actions are consistent with their existing obligations under national and international law [ ... ]' (Tenure Guidelines 8.1). Later, the guidelines remind us that 'states should develop and publicize policies covering the use and control of land, fisheries and forests that are retained by the public sector [ ... ]' (Tenure Guidelines 8.6). Additionally, 'policies for allocation of tenure rights should be consistent with broader social, economic and environmental objectives [... ], and that such policies should ensure that the allocation of tenure rights does not threaten the livelihoods of people by depriving them of their legitimate access to resources' (Tenure Guidelines 8.7).

\section{Promote-Resolution of Agrarian Conflicts}

Guatemala's regulatory frameworks and institutions prioritize the resolution of agrarian conflicts; this makes up the second axis of the Agrarian Policy. In order to engage in any meaningful discussion of agrarian conflicts and the potential for their resolution, it is critical to recognize the context left in the ashes of the Civil War. This is not meant to diminish other waves of dispossession in Guatemala's history, from Spanish conquest to narco-trafficking and northward migration (see [48-50] for a deeper exploration of these issues), but rather to situate unequal land politics as they are, rooted in unresolved conflict.

After the only serious attempt at agrarian reform was made in Guatemala in an effort to undo the colonato landholding regime, the CIA sponsored a coup in 1954. The coup quickly unraveled a decade of democratic reforms directed at shoring up public services (for more on this critical era in Guatemala's history that is beyond the scope of this paper, see [51-53]). The agrarian reform program leading up to the coup had been widely influential among rural poor people throughout Latin America, yet its antagonists, including the U.S. government, maintained that is was an attempt at a communist revolution that would undermine their own mounting regional power. These actions lit the fire of the Civil War that would burn from 1960 until it ended with the Peace Accords in 1996. The Guatemalan state green-lighted the murder of up to 70 percent of its Mayan and peasant Ladino majority population through the notorious scorched earth campaigns. By the time the time the war was over, the military had killed or disappeared more than 200,000 and forcibly evicted up to 2.5 million in what a UN-sponsored truth commission would later classify as genocide [53,54]. Eighty-three percent of them were Indigenous Mayans. Not even the Peace Accords could not pave the way for rule by the oppressed majority - as was the case coming out of similar struggles, such as in Bosnia and South Africa-and they amounted to an unspecified remedy, rather than a real 'right to restitution' [52].

Issues related to peasant land sellers are a main source of agrarian conflict today, and are firmly rooted in the injustices of the past. Previous government action and Guatemala's current regulatory framework stress the importance of land titles without provision of technical assistance or ways to access capital. These factors made Indigenous peoples more vulnerable to kinds of land grabbing in which investors and elites compel peasants to sell the highest quality lands [39]. The political pressure rural working people encounter when it comes to selling their land often involves trickery and arm-twisting. Although government officials and land policy use the World Bank language of 'willing buyers and sellers', land transfers in practice often violate international human rights instruments such as Free Prior and Informed Consent (FPIC).

Peasant land sellers often find themselves between a rock and a hard place. Trust can be shattered in a community when local land brokers take the place of official corporate representatives, pitting rural workers competing for resources against one another. The phenomenon of agrarian conflict dividing rural workers is has been less explored than traditional conflicts between affected communities 
and corporations and states, but must be taken seriously where powerful actors take advantage of poverty to divide and conquer any potential resistance [55]. And since there has been an upsurge in grievances by agro-extractive industries, causing communities to shut them out and refuse negotiations, middlemen are all the more common. Another area of concern is the case of distressed sales-that is, when peasants find no other option aside from selling their land to obtain the cash they need to deal with pressing necessities. Examples include illness, food procurement, recovering from a natural disaster, and pollution of land and resources by third parties, among others [56]. Again, these instances indicate a lack of public services and protection.

A second group that is highly vulnerable to agrarian conflict is the agricultural work sector. In a system where one plantation economy has replaced another, agricultural workers in Guatemala are in an uphill battle against a past labor regime that has recently undergone a makeover. Agribusiness has, to a large degree, replaced its greedy land-grabbing image with a humanitarian and entrepreneurial one-claiming that agro-extractivism simultaneously responds to rural hunger, mass unemployment, and the climate crisis. To this end, the 'land for food, not for fuel' campaigns advocated for by agrarian and environmental justice movements are met by industrial claims that they are contributors to 'food sovereignty' and job creation. This was illustrated by the Guatemalan Oil Palm Growers Guild (GREPALMA) in its claim that oil palm is a food crop, going as far to advertise it as 'food sovereignty' [57].

Along the road that leads to Sachaj in Alta Verapaz, a billboard stands near the barbed wire fence that guards a massive plantation: 'oil palm for people's food sovereignty', it reads. The oil palm industry has released unofficial figures indicating that it will create direct employment for 28,000 people along with 140,000 indirect jobs [58]. The World Bank's Rising Global Interest in Farmland 2011 report also uses this logic in its assertion that non-forested and potentially arable land throughout the world is widely uninhabited and produces far below its ultimate potential, citing Guatemala as one such case [59].

Residents in Sachaj explained that when oil palm companies hire locally, emphasizing that local hire is never a given, they only hire young people-leaving many out of work and disrupting household farming systems. Salaries are not sufficient, they said, and conditions inside are squalid at best (meeting with the community of Sachaj, 1 April 2015). Wage and labor conditions and arrangements in the Guatemalan oil palm industry are unstable, and often below international standards [60]). Reflecting on the situation, one community member explained how the oil palm company has created a situation of dependency. Out of the average 60 quetzals (about \$7.84) daily payment, at least 30 quetzals are used to pay for food, leaving little to cover the living expenses of those who are not offered work. Villagers in Sachaj additionally indicated that it is common practice for oil palm companies to bring in their own labor forces under the assumption that rural locals from peasant and Indigenous backgrounds will disrupt the remunerative systems that the companies already have in place.

In sum, the crux of contention is that the profit margin of the investor is prioritized over poverty reduction at the local level. Since states are often in competition to lure these investors, they are often willing to give up land on the cheap, or even for free-as long as the 'job creation' narrative removes them from accusations regarding rights violations [61]. It is likely through this logic that that the Guatemalan government justifies the incorporation of Convention 169 of the International Labor Organization into its Agrarian Policy. Since the corporations claim to offer protection for their workers, the state has largely forfeited its oversight responsibilities leaving a growing population without access to land at the mercy of fluctuating and profit-seeking markets.

International human rights instruments address cases of agrarian conflict where rural workers have no existing access to land and natural resources, but not as a result of violent expulsion. This comes to light in cases where Indigenous peasants sold their land as a result of coercion and/or are themselves rural workers in agricultural flex crop plantations, discussed above. A key point of departure here is the applicability of FPIC. FPIC was initially sketched within the framework of ILO convention 169, and then incorporated into the UN Declaration on the Rights of Indigenous Peoples, adopted 
by the General Assembly in 2007. FPIC is meant to accompany the Tenure Guidelines, providing measures that will simultaneously respect traditional land rights and promote access to resources. It does so by detailing what giving up consent could look like in a given community, calling for extensive consultation measures in communities where land deals are proposed. On one side, merely getting to the point of folding FPIC into international jurisdiction was a hard-fought battle, won after years of struggle in Indigenous and other marginalized communities. But on the other side, FPIC has become a highly misinterpreted tool that facilitators of large-scale land deals have used to legitimize them - thus expediting their implementation [62].

Despite its vulnerability, when FPIC is implemented where consent, and not just consultation, is aligned with community agreement, it can be a powerful tool. The gray area between consent and consultation further weakens Guatemala's Agrarian Policy. By focusing on consultations, the policy fails to clarify that legitimate conversations in full disclosure of development objectives put all outcomes on the table and respect the decision of the community affected by the given land deal. Specifically, this includes the right to say 'no' as detailed in the FAO Technical Guide No. 3 on how to implement FPIC, where, 'companies and governments engaging in good-faith negotiations with communities must recognize that even when a thorough information and negotiation process has been carried out, Indigenous peoples and local communities have the right to say 'no' to development or to a project on their customary lands'. These measures, taken together with the Tenure Guidelines, require redistributive reforms-which would amount to an overhaul of the private property system. (The kinds of reforms that favor Indigenous peasant communities should not be mistaken with the MLAR programs previously analyzed in this paper.)

Section fifteen of the Tenure Guidelines deals exclusively with redistributive reforms in a way that could lead to a comprehensive agrarian reform in Guatemala that is inclusive of territory. The guidelines acknowledge that redistributive reforms can 'facilitate broad and equitable access to land and inclusive rural development' (Tenure Guidelines 15.1). These reforms 'may be considered for social, economic and environmental reasons, among others, where a high degree of ownership concentration is combined with a significant level of rural poverty attributable to lack of access to land, fisheries and forests [ ... ]' (Tenure Guidelines 15.3). A good starting point for redistributive reforms where high ownership and rural poverty coincide is the policy option of land ceilings (see Tenure Guidelines 15.2). In the case of Guatemala, these land ceilings could be a first step towards dismantling colonato landholdings.

Informal tenure, as specified in section ten of the Tenure Guidelines, works in close collusion with redistributive reforms-most poignantly as it applies to workers and protecting their tenancy rights. As described, oil palm workers face rights violations and lack of public accountability in the plantations daily. Their grievances-from low wages, to health concerns, to job security-are representative of what workers encounter throughout Guatemala. One serious violation is nonexistent land access, often amounting to informal tenure, as is the case with voluntary or coerced sellers who have turned to plantation work. The guidelines stipulate that where informal tenure exists: 'States should acknowledge it in a manner that respects existing formal rights under national law and in ways that recognize the reality of the situation and promote social, economic and environmental well-being' (Tenure Guidelines 10.1). These affected individuals and communities should be afforded the opportunity to be part of the process of establishing laws and policies in a gender-sensitive and participatory manner with 'special attention to farmers and small-scale food producers' (Tenure Guidelines 10.1 and 10.3). Mechanisms for informal tenure are an urgently important tool, especially as they apply to women.

\section{Restore-Legal Guarantees and Security and Productive Assets}

The final two axes of Guatemala's Agrarian Policy are legal guarantees and security, and access to other productive assets. These priorities are discussed here in relation to restoration, that is, returning land and natural resources to their customary guardians via land restitution and other vehicles. The 
Agrarian Policy does make mention of restitution of rights compensation and land acquisition for high impact conflicts (see Agrarian Policy 2.3); however, the focus is on compensatory measures to be managed by the Secretary of Agrarian Affairs and FONTIERRAS. This echoes the logic written into the Peace Accords-proposing similar measures that have proven unsuccessful in the past-focusing on cadastral land management systems rooted in private property. It is worth repeating that the policy makes no mention of, a) those displaced by the civil war, and b) people now landless due to agrarian and environmental extractivist projects.

The Tenure Guidelines can be used to restore access to rural workers who have been rendered landless, especially where states are bound by international law. The guidelines state that 'where possible, the original parcels or holdings should be returned to those who suffered the loss, or their heirs, by resolution of the competent national authorities' (Tenure Guidelines 14.2). This resonates strongly in Guatemala, where Indigenous tenure systems are based on principles such as cosmovision and territory, and were eradicated during the Civil War. Restitution programs following the Peace Accords focused on shanty housing on the outskirts of urban areas and monetary compensation [52]. Since monetary compensation was attached to proof of titles and identity documents that either never existed under customary Indigenous systems or was lost when people fled scorched earth campaigns, more often than not, the funds never arrived. This contributed to yet another wave of displacement as unemployment and narco-trafficking have rocked Guatemala's cities and sent their most vulnerable inhabitants across borders in an attempt to seek work. These cycles are being repeated through a technically narrow cadastral system. For this reason, it is crucial that the particular 'concerns of Indigenous peoples regarding restitutions should be addressed in the national context and in accordance with national law and legislation' (Tenure Guidelines 14.3).

Turning to the third axis of Agrarian Policy, legal guarantees and security, the Guatemalan state shows a commitment on paper to strengthening traditional tenure systems and communal land management and subsequently references the historical rights of communities. In Guatemala, like elsewhere in the Americas, traditional land tenure systems are not limited to, but largely revolve around an Indigenous heritage and customary resource management. However, the regulatory framework once again hands over power to the Secretary of Agrarian Affairs, FONTIERRAS, and RIC through the establishment of a land tenure regularization law. This occurs despite the fact that the ability to pass legislation extends beyond the state's executive branch. Implementation is again left vague. Fully incorporating chapter nine of the Tenure Guidelines that refers to Indigenous peoples and other communities with customary tenure systems throughout this clause of the Agrarian Policy could redress this gray area.

The Tenure Guidelines also offer a human rights-based point of reference for restoring democratic land access for Indigenous peoples and other groups who were made landless by violent or other means and wish to return to their homelands or those of their ancestors (where possible). To this end, 'State and non-state actors should acknowledge that land, fisheries and forests have social, cultural, spiritual, economic, environmental and political value to Indigenous peoples and other communities with customary tenure systems' (Tenure Guidelines 9.1). This point is intentionally repeated through several chapters of the Tenure Guidelines, as it is a fundamental human rights-based starting point for lawmaking around land where social actors and leadership predate the modern state and market allocation tendencies.

Communal land management requires some of the most sophisticated forms of legal guarantees and security where it deals with the grievances of the most marginalized and people working in rural areas. A main source of those grievances is the expanding agro-extractive industry; it operates mainly outside of the law, although it should be held to the highest legal standards. Residents of the Raxruhá municipality affected by the oil palm industry have organized collective actions against the corporation. In one such instance, Raxruhá's municipal council leveraged one of the government's key organizing tools, land use taxes, which are not paid by oil palm companies. The municipality planned to use the money to mend some of the damage the corporations had caused in their area, and the 
mayor offered to take the lead. However, the 'Coordinating Committee of Agricultural, Commercial, Industrial, and Financial Associations' (CACIF) took the mayor to court. CACIF is a representative of the flex cropping industry, and its power should not be underestimated. It is 'the key "uncivil" actor of Guatemalan civil society because of its historical propensity to support non-democratic politics and, more broadly, through its attempts to limit citizenship rights in order to preserve economic privileges' [63]. The court ruled in favor of the oil palm companies and sued the mayor. The mayor still sees the action as a victory and said that Raxruhá was unique in its bold decision to identify strategies to defend its land and territory against such heavy interests (meeting with Mayor of Raxruhá, 1 April 2015).

The final axis of Guatemala's Agrarian Policy is access to other productive assets, which is couched in a stated strategy to uplift the peasant economy. At its most fundamental level, this axis recognizes that land alone is not enough without additional means of livelihood production. However, the Agrarian Policy continues to give preference to using competition in rural areas to boost the national economy and leans on market mechanisms to do so. In short, it hinges on public-private partnerships. Human rights instruments can help shift this priority towards public-peasant partnerships [64]), that is, encouraging states to redouble their commitment to peasant-majority constituencies and their grassroots efforts regarding resource tenure.

The Tenure Guidelines offer guidance here in chapters 11 and 12, which reference markets and investments subsequently. As a point of departure, 'states should simplify administrative procedures in order to avoid discouragement of market participation by the poor and most vulnerable' (Tenure Guidelines 11.3). Even though this is focused here on land markets, they are dealt with as part of and in relationship to other sectors of the economy, namely subsistence and small-scale farmers. Specifically, 'given the importance of small-scale producers for national food security and social stability, States should ensure that when facilitating market operations of tenure transactions, they protect the tenure rights of small-scale food producers' (Tenure Guidelines 11.8). Another important application of the Tenure Guidelines in this regard has to do with investment. More than ever, 'considering that smallholder producers and their organizations in developing countries provide a major share of agricultural investments that contribute significantly to food security, nutrition, poverty eradication and environmental resistance, States should support investments by smallholders as well as public and private smallholder-sensitive investments' (Tenure Guidelines 12.2).

There are well-documented examples both at national and regional scales, making the case for the consideration of family farmers as powerful economic actors, instead of either as 'inefficient' or social actors deserving only social funds from the government. Nationally, family farmers contribute to employment, and regionally, peasant-to-peasant agroecological exchanges and public marketplaces encourage modern family farming, as those practices have historically been Guatemala's life source [60]. These two strategies include complementary tools already being used on the ground and promoted by grassroots organizations that can be further developed with increased public support, from strengthening rural extension services to lifting up community organizing. Not only do these measures contribute to strong and self-sufficient communities, but they also help secure land and resource tenure. Overall, it is critical that Guatemala recognizes the vast amounts of investments that rural working people engage in within their own communities and treat them as primary investors and, as such, as key economic actors for broader issues around growth and development. This requires a shift in power dynamics, in which the state must reprioritize its food providing and Indigenous majority.

\section{Synthesis and Recommendations}

It has now been more than ten years since the global land rush altered natural resource dynamics indefinitely; it has been five since Guatemala presented its Agrarian Policy, reportedly taking its cue from the Tenure Guidelines. In that amount of time, Guatemala's peasant and Indigenous majority have experienced a rollback of their rights due to increased ecological destruction, waves of land grabbing and rural hunger, and a political system that is unraveling the rule of law in a slow-motion coup. 
These trends reflect regional and global concerns, where the climate crisis is worse than previously imagined, and right-wing authoritarian regimes focus on extractivism at all costs [65]. Indeed, the triad of resource extraction, climate chaos, and gutted democratic structures bears down most heavily on women, peasants, and Indigenous people in the countryside.

The Tenure Guidelines were never meant to be a piecemeal policy remedy; they are a political tool that works best in combination with other forms of human rights-based legislation. A complementary right to land framework is guided by respect for and protection of existing land and resource access, promotion of redistributive reforms, and restoration of land access through land restitution and other means [2]. Applying this framework to legislation can point to settings where favorable policies are absent, contradictory, partial, or dormant. The Tenure Guidelines in fact bridge two extremes, where one end of the spectrum is a political reality that is sidelining the most marginalized (i.e., Agrarian Policy), and the other is the intention of empowerment (i.e., Right to Land). When used together with other global governance mechanisms, especially the Rights of Indigenous Peoples and the Rights of Peasants and Other People Working in Rural areas-the Tenure Guidelines can provide clear and prescriptive steps about how to how to cross this footbridge towards empowerment, while avoiding the dangers of falling into cooptation.

So where do we go from here? Justice and equality in Guatemala and elsewhere clearly have many different expressions, but the lynchpin is land. More precisely, the articulation for a right to land, at the intersection of democratic land control and human rights. The Tenure Guidelines have set an international standard in struggles to advance natural resource rights, putting forth minimum measures that states can take to win those rights for all of their citizens. A variety of stakeholders are implicated in the interpretation and implementation of the Tenure Guidelines. They include, but are not limited to national governments, international intergovernmental organizations, social movements and NGOs, branches of the United Nations, and academic research. Positive courses of action for these stakeholders are explored in brief below.

The role of the state is vital, perhaps now more than ever. As national governments around the world follow privatization trends, the agricultural sector is increasingly outsourced to corporations and where states are more actively involved it is often in a way that encourages public-private partnerships. These political arrangements can have devastating effects on the lives and livelihoods of small-scale food producers and often result in land and resource grabbing. The Tenure Guidelines are a way to bring back the central role of the state in governing land and resource tenure issues. It is important for the state to use the guidelines in large part to protect those who have access to land and resources, but are under threat of losing that access. This can take the shape of having access without land, or land without (real) access.

International intergovernmental organizations have an unprecedented political opportunity created by the Tenure Guidelines. The World Bank has stated its strong support for the guidelines and is therefore in a place where it can reform its development strategy to one that is in sync with the Tenure Guidelines and its own stated goals of 'ending extreme poverty' and 'promoting shared prosperity' [66]. Against the backdrop of land and resource grabbing that contribute to poverty instead of relieving it; the World Bank should take a hard look at its preferred market-led strategies with the Tenure Guidelines and change courses to a rights-based strategy. Even though the World Bank has stated its support for the Tenure Guidelines, it must adjust its interpretation in a way that aligns with marginalized communities. New research within its Land Governance Assessment Framework is timely. Financial institutions that support flex-crop development initiatives in the region are also implicated here. The Inter-American Development Bank, which finances the Mesoamerican Integration Development Project—including the Puebla-Panama Plan—is a key player in Guatemala, and thus another actor for which the rights-based resource governance strategy indicated in the Tenure Guidelines should apply.

Social movements and grassroots organizations play a strong role in holding governments accountable, and the Tenure Guidelines are a perfect accountability mechanism for land access. These 
alliances, as well as NGOs, have four main leverage points with the Tenure Guidelines across local and national policies. First, in settings where there are not policies to protect, promote, and restore democratic land access and human rights, social actors should use the Tenure Guidelines as a substitute-especially where their governments are signatories. A second access point is in settings where policies to protect, promote, and restore land rights are flawed. Here, the Tenure Guidelines should be advocated in a way that provides a corrective measure. Third, in settings where policies to protect, promote, and restore land access are insufficient, the Tenure Guidelines can be used by movements to fill the gap. Finally, in settings where policies to protect, promote, and restore democratic land access and human rights exist, rural social movements and NGOs should use the Tenure Guidelines as a means of policy implementation. More specifics around understanding the Tenure Guidelines and using them as a tool for policy analysis and advocacy can be found in the 'popular manual' for communities and movements [67].

Partnerships between United Nations branches-especially FAO, the International Fund for Agricultural Development (IFAD), and the United Nations Environment Programme (UNEP)—and social movements and NGOs are key alliances, many of which have grown significantly over the past years. Through these processes, UN policymaking bodies are able to hear from rural working people themselves and prioritize their rights and solutions into international human rights law. It was in fact, this kind of dynamic and mutually reinforcing relationship that resulted in the Tenure Guidelines. FAO, IFAD, and UNEP should further prioritize these voices in implementation of their political tools. The emerging right to land energizes this priority. FAO, IFAD, and UNEP should insert critical input throughout this process, pushing for a formulation that combines democratic land access and human rights in a right to land formulation that protects, promotes, and restores (real) access to land and natural resources. More conversations around food and land sovereignty are an integral part of this formulation. Finally, when engaging with social actors, the overlap of agrarian and environmental issues is creating new spaces for convergence between grassroots movements and UN branches. These issues are also of relevance to the Inter-American System of Human Rights Bodies. Discussions must be held across these spaces, and from the grassroots up.

For scholars of agrarian political economy and political ecology, human rights investigations that cut across these areas of study can result in research that is at once scientifically rigorous and socially relevant. The Tenure Guidelines can be used as a measuring stick for democratic land access and human rights where resource accumulation and other processes put those rights under direct threat. The theoretical handles of protect, promote, and restore as concepts and policies give academics a way to move with intent between local and global settings-grounding analysis with singular or comparative case studies and international trends. The same is true with the parallel process of absent law/policy, partial law/policy, and contradicting law/policy. Rights-based framing is a methodological approach where academic research and policymaking can acquiesce. Critical studies on the Tenure Guidelines are also relevant, as well as the guidelines use with other international human rights tools, and comparative analysis-weaving in local, regional, and transnational insights.

The case of Guatemala offers many takeaways. Its Agrarian Policy is, on the one hand, both a vague and visionary document-telling us what needs to be done, but offering few instructions on how to get there. On the other hand, where more specific remedial measures are offered, they tend to be extensions of the Peace Accords that were written at the pinnacle of neoliberal globalization. Thus, the policy favors economic growth strategies that expose deep chasms left in the wake of history; today, race, class, gender, and other levers of oppression only reinforce them. These factors have collided forcefully with the worsening climate crisis and authoritarian politics. But if Guatemala were to meaningfully incorporate the Tenure Guidelines and other human rights-based tools into its Agrarian Policy-rather than coopting them-it would set a regional standard and could begin to redress the balance.

Funding: This research received no external funding 
Acknowledgments: Many thanks to Jose Luis Caal Hub, Jun Borras, Zoe Brent, Alberto Alonso-Fradejas, Ben McKay, Christina Schiavoni, Joel Lopez, and two anonymous peer reviewers who accompanied this process in unique and irreplaceable ways. I would also like to warmly acknowledge the support of the United Nations Food and Agriculture Organization (FAO) in conducting the research. Above all, I am grateful for the social justice movements that work tirelessly for system change in Guatemala and beyond.

Conflicts of Interest: The author declares no conflict of interest

\section{References}

1. Bernstein, H. Class Dynamics of Agrarian Change; Kumarian Press: Sterling, VA, USA, 2010; Volume 1.

2. Franco, J.C.; Monsalve, S.; Borras, S.M. Democratic land control and human rights. Curr. Opin. Environ. Sustain. 2015, 15, 66-71. [CrossRef]

3. De Schutter, O. The emerging human right to land. Int. Community Law Rev. 2010, 12, 303-334. [CrossRef]

4. FAO. Country Fact Sheet on Food and Agriculture Policy Trends, Guatemala; FAPDAFAO: Rome, Italy, 2014; Available online: http://www.fao.org/3/a-i4124e.pdf (accessed on 12 May 2018).

5. Tenure Guidelines. Voluntary Guidelines on the Responsible Governance of Tenure of Land, Fisheries and Forests in the Context of National Food Security; Food and Agriculture Organization of the United Nations: Rome, Italy, 2012; Available online: http://www.fao.org/tenure/voluntary-guidelines/en/ (accessed on 16 May 2019).

6. Windfuhr, M. FAO: Voluntary Guidelines on Responsible Governance of Tenure of Land, Forests and Fisheries-Relevance, Reception and First Experiences in Implementation. In International Yearbook of Soil Law and Policy 2016; Springer: Cham, Switzerland, 2017; pp. 203-218.

7. Seufert, P. The FAO voluntary guidelines on the responsible governance of tenure of land, fisheries and forests. Globalizations 2013, 10, 181-186. [CrossRef]

8. Franco, J.; Monsalve Suárez, S. Why wait for the state? Using the CFS Tenure Guidelines to recalibrate political-legal struggles for democratic land control. Third World Q. 2018, 39, 1386-1402. [CrossRef]

9. Brent, Z.W.; Alonso-Fradejas, A.; Colque, G.; Sauer, S. The 'tenure guidelines' as a tool for democratising land and resource control in Latin America. Third World Q. 2018, 39, 1367-1385. [CrossRef]

10. McKay, B.M. Democratising land control: Towards rights, reform and restitution in post-conflict Colombia. Can. J. Dev. Stud. 2018, 39, 163-181. [CrossRef]

11. Franco, J.; Kramer, T.; Fradejas, A.A.; Twomey, H.; Vervest, P. The Challenge of Democratic and Inclusive Land Policymaking in Myanmar: A Response to the Draft National Land Use Policy; Transnational Institute (TNI): Amsterdam, The Netherlands, 2015; pp. 1-72.

12. Government of Guatemala. Política Agraria Acuerdo Gubernativo 372-2014. In Secretaría de Asuntos Agrarios de la Presidencia de la República de Guatemala; 2014. Available online: http:/www.segeplan.gob.gt/downloads/ clearinghouse/politicas_publicas/Desarrollo\%20Agropecuario/Politica_Agraria_2014.pdf (accessed on 14 August 2019).

13. Tramel, S.; Caal Hub, J.L. Interpreting and Using the Voluntary Guidelines on the Responsible Governance of Tenure of Land, Fisheries and Forests in the Context of National Food Security in Guatemala: Challenges for Democratizing land, Fisheries and Forests Tenure. Presented at the Initiatives in Critical Agrarian Studies, The Hague, The Netherlands, 4-5 February 2016; Institute of Social Studies (ISS), ICAS: The Hague, The Netherlands, 2016.

14. Ribot, J.C.; Peluso, N.L. A theory of access. Rural Sociol. 2003, 68, 153-181. [CrossRef]

15. INE. Censo Nacional Agropecuario; Instituto Nacional de Estadistica: Guatemala City, Guatemala, 2003.

16. Grandia, L. Enclosed: Conservation, Cattle, and Commerce among the Qeqchi Maya Lowlanders; University of Washington Press: Washington, DC, USA, 2012.

17. Ybarra, M. Living on Scorched Earth: The Political Ecology of Land Ownership in Guatemala's Northern Lowlands; University of California: Berkeley, CA, USA, 2010.

18. Holt-Giménez, E. Territorial Restructuring and the Grounding of Agrarian Reform: Indigenous Communities, Gold Mining and the World Bank; Land and International Development Agencies Paper Series; Transnational Institute and the North-South Coalition of Movements: Amsterdam, The Netherlands, 2008; Available online: https://www.tni.org/en/publication/territorial-restructuring-and-the-grounding-of-agrarian-reform (accessed on 12 May 2019).

19. Borras, S.M., Jr.; Franco, J.C. Contemporary discourses and contestations around pro-poor land policies and land governance. J. Agrar. Chang. 2010, 10, 1-32. [CrossRef] 
20. Borras, S.M., Jr.; Franco, J.C.; Gómez, S.; Kay, C.; Spoor, M. Land grabbing in Latin America and the Caribbean. J. Peasant Stud. 2012, 39, 845-872. [CrossRef]

21. Borras, S.M., Jr.; Franco, J.C.; Isakson, S.R.; Levidow, L.; Vervest, P. The rise of flex crops and commodities: Implications for research. J. Peasant Stud. 2016, 43, 93-115. [CrossRef]

22. Alonso-Fradejas, A.; Liu, J.; Salerno, T.; Xu, Y. Inquiring into the political economy of oil palm as a global flex crop. J. Peasant Stud. 2016, 43, 141-165. [CrossRef]

23. McKay, B.; Sauer, S.; Richardson, B.; Herre, R. The political economy of sugarcane flexing: Initial insights from Brazil, Southern Africa and Cambodia. J. Peasant Stud. 2016, 43, 195-223. [CrossRef]

24. Kröger, M. The political economy of 'flex trees': A preliminary analysis. J. Peasant Stud. 2016, 43, 886-909. [CrossRef]

25. McMichael, P. The land grab and corporate food regime restructuring. J. Peasant Stud. 2012, 39, 681-701. [CrossRef]

26. Alonso-Fradejas, A.; Hub, J.L.C.; Miranda, T.C. Plantaciones agroindustriales, dominación y despojo indígena-campesino en la Guatemala del s. XXI. 2011. Available online: https://valledelpolochic.files.wordpress. com/2010/09/plantaciones_y_despojo-guatemala-sxxi-2-copia.pdf (accessed on 5 November 2019).

27. World Bank. World Development Report 2008: Agriculture for Development; Oxford University Press: New York, NY, USA, 2007.

28. Pietilainen, E.P.; Otero, G. Power and dispossession in the neoliberal food regime: Oil palm expansion in Guatemala. J. Peasant Stud. 2018. [CrossRef]

29. Hervas, A. Land, development and contract farming on the Guatemalan oil palm frontier. J. Peasant Stud. 2019, 46, 115-141. [CrossRef]

30. Mingorría, S. Violence and visibility in oil palm and sugarcane conflicts: The case of Polochic Valley, Guatemala. J. Peasant Stud. 2018, 45, 1314-1340. [CrossRef]

31. Granovsky-Larsen, S. Dealing with Peace: The Guatemalan Campesino Movement and the Post-Conflict Neoliberal State; University of Toronto Press: Toronto, ON, Canada, 2019.

32. Copeland, N. Meeting peasants where they are: Cultivating agroecological alternatives in neoliberal Guatemala. J. Peasant Stud. 2019, 46, 831-852. [CrossRef]

33. Einbinder, N.; Morales, H.; Mier Y Terán-Giménez Cacho, M.; Aldasoro, M.; Ferguson, B.G.; Nigh, R. Agroecology on the periphery: A case from the Maya-Achí territory, Guatemala. Agroecol. Sustain. Food Syst. 2019. [CrossRef]

34. Parraguez-Vergara, E.; Contreras, B.; Clavijo, N.; Villegas, V.; Paucar, N.; Ther, F. Does indigenous and campesino traditional agriculture have anything to contribute to food sovereignty in Latin America? Evidence from Chile, Peru, Ecuador, Colombia, Guatemala and Mexico. Int. J. Agric. Sustain. 2018, 16, 326-341. [CrossRef]

35. Government of Guatemala. Constitución Política De La República De Guatemala (archived by UNHCR). 1993. Available online: https://www.acnur.org/fileadmin/Documentos/BDL/2001/0134.pdf (accessed on 2 July 2019).

36. Short, N. The International Politics of Post-Conflict Reconstruction in Guatemala; Palgrave Macmillan US: London, UK, 2016; p. 188.

37. Social Movements, Indigenous Politics and Democratisation in Guatemala, 1985-1996. Available online: https://risweb.st-andrews.ac.uk/portal/en/researchoutput/social-movements-indigenous-politicsand-democratisation-in-guatemala-19851996(9dabd022-c54e-4463-b18f-29af5f366abb)/export.html (accessed on 5 November 2019).

38. Granovsky-Larsen, S. Between the bullet and the bank: Agrarian conflict and access to land in neoliberal Guatemala. J. Peasant Stud. 2013, 40, 325-350. [CrossRef]

39. Gauster, S.; Ryan Isakson, S. Eliminating market distortions, perpetuating rural inequality: An evaluation of market-assisted land reform in Guatemala. Third World Q. 2007, 28, 1519-1536. [CrossRef]

40. Hurtado, L. Dinámicas agrarias y reproducción campesina en la globalización: El caso de Alta Verapaz, 1970-2007; F\&G Editores: Guatemala City, Guatemala, 2008.

41. Alonso-Fradejas, A.; Alonzo, F.; Dürr, J. Caña de azúcar y palma africana: Combustibles para un nuevo ciclo de acumulación y dominio en Guatemala; Instituto de Estudios Agrarios y Rurales (IDEAR), Coordinación de ONG y Cooperativas (CONGCOOP): Guatemala City, Guatemala, 2008. 
42. Cousins, B. How do rights become real?: Formal and informal institutions in South Africa's land reform. IDS Bull. 1997, 28, 59-68. [CrossRef]

43. Fox, J. The Politics of Food in Mexico: State Power and Social Mobilization; Cornell University Press: Ithaca, NY, USA, 1993.

44. Lahiff, E.; Borras, S.M., Jr.; Kay, C. Market-led agrarian reform: Policies, performance and prospects. Third World Q. 2007, 28, 1417-1436. [CrossRef]

45. Alonso-Fradejas, A. Land control-grabbing in Guatemala: The political economy of contemporary agrarian change. Can. J. Dev. Stud. 2012, 33, 509-528. [CrossRef]

46. Castro, J.; Picq, M.L. Stateness as landgrab: A political history of Maya dispossession in Guatemala. Am. Q. 2017, 69, 791-799. [CrossRef]

47. Macours, K. Ethnic divisions, contract choice, and search costs in the Guatemalan land rental market. J. Comp. Econ. 2014, 42, 1-18. [CrossRef]

48. Restall, M.; Asselbergs, F.G.L. Invading Guatemala: Spanish, Nahua, and Maya Accounts of the Conquest Wars; Penn State Press: University Park, PA, USA, 2007; Volume 2.

49. Corva, D. Neoliberal globalization and the war on drugs: Transnationalizing illiberal governance in the Americas. Political Geogr. 2008, 27, 176-193. [CrossRef]

50. Ogren, C. Migration and human rights on the Mexico-Guatemala border. Int. Migr. 2007, 45, $203-243$. [CrossRef]

51. Grandin, G. The instruction of great catastrophe: Truth commissions, national history, and state formation in Argentina, Chile, and Guatemala. Am. Histor. Rev. 2005, 110, 46-67. [CrossRef]

52. Williams, R.C. The Contemporary Right to Property Restitution in the Context of Transitional Justice; International Center for Transitional Justice: New York, NY, USA, 2007.

53. Ybarra, M. 'Privatizing the Tzuultaq'a? Private Property and Spiritual Reproduction in Post-War Guatemala'. J. Peasant Stud. 2011, 38, 793-810. [CrossRef]

54. Center for Historical Clarification (CEH) 1999: Guatemala: Memoria de Silencio. Available online: http://www.centrodememoriahistorica.gov.co/descargas/guatemala-memoria-silencio/guatemalamemoria-del-silencio.pdf (accessed on 5 November 2019).

55. Borras, S.M., Jr.; Franco, J.C.; Wang, C. The challenge of global governance of land grabbing: Changing international agricultural context and competing political views and strategies. Globalizations 2013, 10, 161-179. [CrossRef]

56. Maxwell, D.; Wiebe, K. Land tenure and food security: Exploring dynamic linkages. Dev. Chang. 1999, 30, 825-849. [CrossRef]

57. Hunsberger, C.; Alonso-Fradejas, A. The discursive flexibility of 'flex crops': Comparing oil palm and jatropha. J. Peasant Stud. 2016, 43, 225-250. [CrossRef]

58. GREPALMA. Desarrollo Para Guatemala. 2019. Available online: https://www.grepalma.org/desarrollopara-guatemala/ (accessed on 29 June 2019).

59. Deininger, K.; Byerlee, D. Rising Global Interest in Farmland: Can It Yield Sustainable and Equitable Benefits? The World Bank: Washington, DC, USA, 2011.

60. Alonso-Fradejas, A. Anything but a story foretold: Multiple politics of resistance to the agrarian extractivist project in Guatemala. In Global Land Grabbing and Political Reactions' from Below'; Routledge: Abingdon-on-Thames, UK, 2017; pp. 23-50.

61. Li, T.M. Centering labor in the land grab debate. J. Peasant Stud. 2011, 38, 281-298. [CrossRef]

62. Franco, J. Reclaiming Free Prior and Informed Consent (FPIC) in the Context of Global Land Grabs; Transnational Institute (TNI): Amsterdam, The Netherlands, 2014.

63. Krznaric, R. Civil and uncivil actors in the Guatemalan peace process. Bull. Latin Am. Res. 1999, 18, 1-16. [CrossRef]

64. Kay, S. Reclaiming Agricultural Investment: Towards Public-Peasant Investment Synergies. TNI Agrarian Justice Programme Policy Paper; Transnational Institute: Amsterdam, The Netherlands, 2014; Available online: http://www.tni.org/sites/www.tni.org/files/download/reclaiming_agricultural_investment.pdf (accessed on 21 June 2019).

65. Scoones, I.; Edelman, M.; Borras, S.M., Jr.; Hall, R.; Wolford, W.; White, B. Emancipatory rural politics: Confronting authoritarian populism. J. Peasant Stud. 2018, 45, 1-20. [CrossRef] 
66. The World Bank Group Goals: End Extreme Poverty and Promote Shared Prosperity. The World Bank: Washington, DC, USA, 2013. Available online: https:/www.worldbank.org/content/dam/Worldbank/ document/WB-goals2013.pdf (accessed on 31 October 2019).

67. Ortega-Espés, D.; Highton, A.C.; Strappazzon, Á.; Pedot, E.; Tzeiman, A.; Icaza, M.S.; Seufert, P. Manual Popular de las Directrices Voluntarias sobre la Gobernanza Responsable de la Tenencia de la Tierra, la pesca y los Bosques en el Contexto de la Seguridad Alimentaria Nacional; Guía para la promoción, la aplicación, el monitoreo y la evaluación; Comité Internacional de Planificación para la Soberanía Alimentaria: Amsterdam, The Netherlands, 2015.

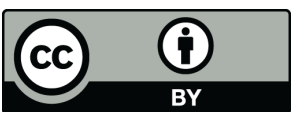

(C) 2019 by the author. Licensee MDPI, Basel, Switzerland. This article is an open access article distributed under the terms and conditions of the Creative Commons Attribution (CC BY) license (http://creativecommons.org/licenses/by/4.0/). 